\title{
Anesthesia Management of a Super-Obese Patient with a Body Mass Index of $65.5 \mathrm{~kg} / \mathrm{m}^{2}$
}

\author{
Sukru Mert Baspinar *, Demet Sergin, Abdurrahim Derbent \\ Ege University, Faculty of Medicine, Department of Anesthesiology and Reanimation, 35100 Bornova, Izmir, Turkey. \\ *Corresponding Author: Sukru Mert Baspinar, Ege University, Faculty of Medicine, Department of Anesthesiology and Reanimation, 35100 \\ Bornova, Izmir, Turkey. \\ Received date: March 01, 2021; Accepted date: April 07, 2021; Published date: April 13, 2021 \\ Citation: Sukru M Baspinar, D Sergin, A Derbent. (2021) Anesthesia Management of a Super-Obese Patient with a Body Mass Index of \\ $65.5 \mathrm{~kg} / \mathrm{m} 2$. International Journal of Clinical Case Reports and Reviews. 7(1); DOI:10.31579/2690-4861/121
}

Copyright: ( 2021 Sukru Mert Baspinar, This is an open-access article distributed under the terms of the Creative Commons Attribution License, which permits unrestricted use, distribution, and reproduction in any medium, provided the original author and source are credited.

\begin{abstract}
Obesity is one of the most common health issues in the world. It is defined based on body mass index (BMI), that is, the ratio of weight (in kilograms) to the square of height (in meters). World Health Organization defines an adult with a BMI $\geq 30 \mathrm{~kg} / \mathrm{m}^{2}$ as obese. In the case of surgical intervention in an obese patient particular anesthetic procedure might be required. In this case report, we present our experience in the management of anesthesia during head and neck surgery which was performed on a 66 years old, $172 \mathrm{~kg}$ super-obese patient diagnosed with laryngeal cancer.
\end{abstract}

Keywords: anesthesia management; anesthesia management; body mass index

\section{Introduction}

Obesity is one of the most common health issues which affects many organ systems. Anesthesia preparation, management and postoperative follow-up of morbidly obese patients are particularly important. Obesity causes respiratory and cardiovascular changes that affect the management of anesthesia and perioperative analgesia. In the respiratory system, tidal volumes are smaller, and in order to compensate it, respiratory rate is higher. Lung volumes are not compliant with the respiratory system. As a consequence, decreasing FRC and ERV are observed [1,2]. These changes have important effects such as decrease in time needed for desaturation during apnea and increase in $\mathrm{O}^{2}$ requirements [3]. Principal cardiovascular changes are increase in circulating blood volume, decrease in systemic vascular resistance, increases in cardiac output and left ventricular hypertrophy.

Due to above mentioned particularities of obese patients, anesthetic drug dosing, patient positioning, airway management, ventilation management, fluid management on the patient become challenging for the anesthesiologists. Here we present our experience in the management of anesthesia during head and neck surgery which was performed on a 66 years old, $172 \mathrm{~kg}$ super-obese patient diagnosed with laryngeal cancer.

\section{Consent for Publication}

The patient provided the written authorization of "Health Insurance Portability and Accountability Act".

\section{Case Description}

In this case report, patient was informed about the study and he provided an informed consent at Ege University Medical Hospital, Department of Anesthesiology and Reanimation. We were granted permission to share this study in the medical literature.
The patient was male and he was 66 years old. His weight was $172 \mathrm{~kg}$ and his height was $162 \mathrm{~cm}$. He was with laryngeal cancer diagnosis which was evaluated for total laryngectomy and left neck dissection operation. The patient had also hypertension, sleep apnea, depression, exercise dyspnea and diabetes mellitus. Patient's body mass index (BMI) was $65.5 \mathrm{~kg} / \mathrm{m} 2$, ideal body weight (IBW) was $58.7 \mathrm{~kg}$ and lean body weight (LBW) was $76.5 \mathrm{~kg}$. Additional preparations were done in the operation hall due to the risk of difficult ventilation and intubation. Due to the lack of hydraulic operating table specially designed for obese patients in our operating room, two operating tables were joined together because the patient could not fit on a single operating table and could have difficulty in giving the position. The patient was taken to the operating room and electrocardiography (ECG), oxygen saturation and non-invasive blood pressure were monitored. The heart rate was $107 / \mathrm{min}$, blood pressure was $143 / 72 \mathrm{mmHg}$ and oxygen saturation was $90 \%$ in the patient and he had an ECG of sinus rhythm. Preoperative oxygenation was performed during 5 min with $100 \%$ oxygen. After intravenous (IV) cannulation, $0.5 \mathrm{mg}$ atropine, $2,5 \mathrm{mg} / \mathrm{kg}$ (LBW) propofol, $1 \mathrm{mcg} / \mathrm{kg}$ (LBW) remifentanil and $0.8 \mathrm{mg} / \mathrm{kg}$ (IBW) rocuronium bromide were administered. Mask ventilation was difficult for one anesthetist so two anesthetists performed mask ventilation. Intubation was performed easily at the time of maximum neuromuscular blockade $(120 \mathrm{sec})$. The patient was ventilated with $50 \%$ oxygen, a $50 \%$ air mixture with $\% 2$ sevoflurane and tidal volume of $480 \mathrm{ml}$.. His respiratory rate was $24 / \mathrm{min}$. Remifentanil infusion of $0.4 \mathrm{mcg} / \mathrm{kg} / \mathrm{min}$ was initiated to provide controlled hypotension. Patient underwent tracheostomy at the second hour due to the surgical procedure. Patient ventilation was continued from the tracheostomy cannula. During the operation, $80 \mathrm{mg}$ rocuronium was administered in the form of additional doses. After 6.5 hours of surgery, patient decurarization was performed with $2 \mathrm{mg} / \mathrm{kg}$ sugammadex. After decurarization, the patient's spontaneous breathing was achieved sufficiently. Follow-up was done in the recovery room of the patient, 
whose vitals were stable. After 30 minutes, respiratory distress occured and saturation was 88 . The patient was transferred to the intensive care unit because of the need for weaning. In the intensive care unit, the patient was followed up with Pressure Support Ventilation (PSV). Pressure values of PS and PEEP were set to 8 and 6, respectively. The percentage of Fio 2 was $\% 40$. After 2 days the patient was separated from mechanical ventilator support. The follow-up was continued with the BIPAP device. On the 5th day the patient was transferred to the otolaryngology clinic. On the 14th day, the patient was discharged with a tracheotomy cannula.

\begin{tabular}{|c|c|}
\hline Body mass index; kg.m ${ }^{2}$ & Classification \\
\hline$<18.5$ & Underweight \\
\hline $18.5-24.9$ & Normal \\
\hline $25.0-29.9$ & Overweight \\
\hline $30.0-34.9$ & Obese 1 \\
\hline $35.0-39.9$ & Obese 2 \\
\hline$>40.0$ & Obese 3 (previouslv 'morbid obesitv') \\
\hline
\end{tabular}

Table 1

\begin{tabular}{|c|c|}
\hline $\begin{array}{l}\text { Total body weight } \\
\text { (TBW) }\end{array}$ & The actual weight of the patient \\
\hline $\begin{array}{l}\text { Ideal body weight } \\
\text { (IBW) }\end{array}$ & $\begin{array}{l}\text { What the patient should weigh with a normal ratio of lean to fat mass. Varies with age, and is usually } \\
\text { approximated to a function of height and sex: } \\
\text { IBW }(\mathrm{kg})=\text { height }(\mathrm{cm})-\mathrm{x}(\text { where } \mathrm{x}=105 \text { in females and } 100 \text { in males })\end{array}$ \\
\hline $\begin{array}{l}\text { Lean body weight } \\
\text { (LBW) }\end{array}$ & $\begin{array}{l}\text { The patient's weight excluding fat. Many of the formulae for calculating lean body weight are complex but } \\
\text { one of the most widely used is that of Janmahasatian et al. } 34 \text { : } \\
\text { LBW }(\mathrm{kg})=9270 \times \mathrm{TBW}(\mathrm{kg}) 6680+(216 \times \mathrm{BMI}(\mathrm{kg} \cdot \mathrm{m}-2))(\mathrm{men}) \\
\text { LBW }(\mathrm{kg})=9270 \times \mathrm{TBW}(\mathrm{kg}) 8780+(244 \times \mathrm{BMI}(\mathrm{kg} \cdot \mathrm{m}-2))(\text { women }) \\
\text { Regardless of total body weight, lean body weight rarely exceeds } 100 \mathrm{~kg} \text { in men and } 70 \mathrm{~kg} \text { in women } \\
\text { (Fig. 2) } 35\end{array}$ \\
\hline $\begin{array}{l}\text { Adjusted body } \\
\text { weight }(\mathrm{ABW})\end{array}$ & $\begin{array}{l}\text { Takes into account the fact that obese individuals have increased lean body mass and an increased volume } \\
\text { of distribution for drugs. It is calculated by adding } 40 \% \text { of the excess weight to the IBW 36: } \\
\mathrm{ABW}(\mathrm{kg})=\mathrm{IBW}(\mathrm{kg})+0.4(\mathrm{TBW}(\mathrm{kg})-\mathrm{IBW}(\mathrm{kg}))\end{array}$ \\
\hline
\end{tabular}

Table 2: The four most useful terms for describing patients' weight

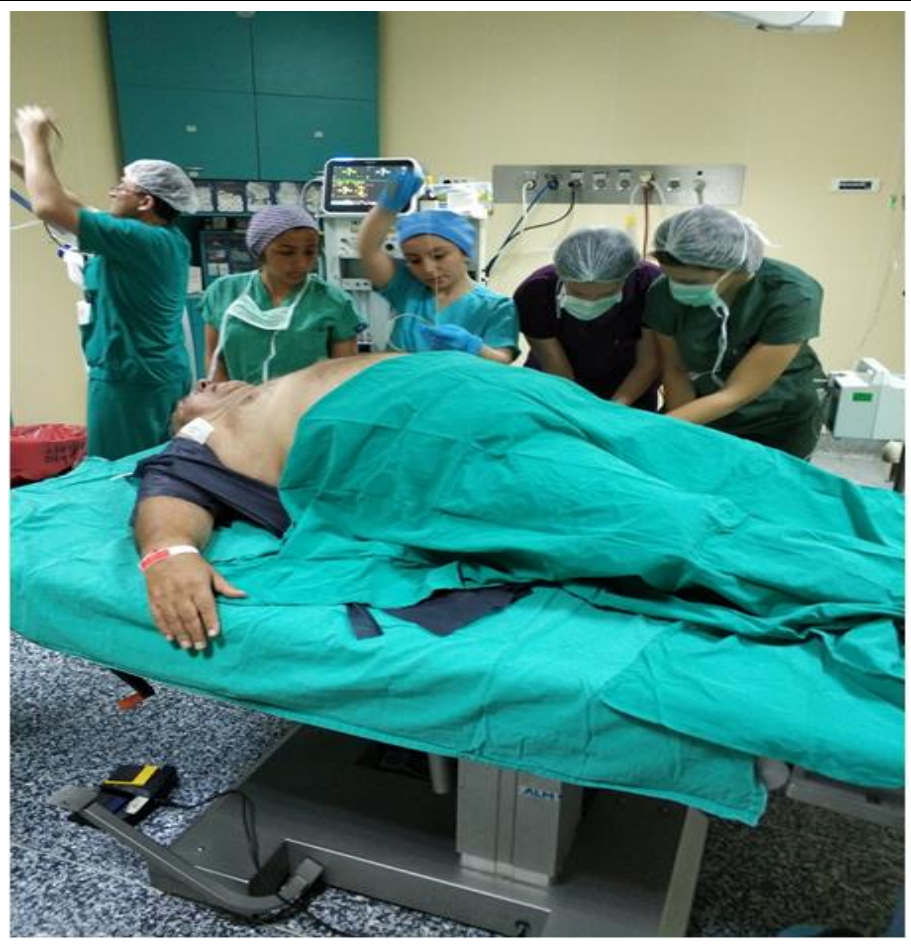

Figure 1

Obesity is a complex disorder involving an excessive amount of body fat.

The factors influencing obesity are endocrine disorders, neurological 
factors, genetic factors, psychological factors, environmental factors, behavioral factors, obesity-causing drugs. Obesity is a disease that affects more than one organ system, especially the cardiovascular and respiratory systems. Body mass index (BMI) is used for obesity classification. This index is obtained by dividing the person's weight (in kilograms) by the length (in meters) of the square. BMI value of our patient was calculated as $65.5 \mathrm{~kg} / \mathrm{m}^{2}$ and it was classified as Obese 3 (previously morbid obesity). The difficulty in mask ventilation in patients with BMI> 26 increased three-fold [4]. Several difficulties related to the obesity of the patient were encountered. It is known that high fat storage in the neck area of an obese patient and a large tongue make laryngoscopy and intubation difficult [5]. Difficult intubation is more common in obese than in lean patients, with a difficult intubation rate of $15.5 \%$ in obese patients (BMI $>35 \mathrm{~kg} \mathrm{~m}^{-2}$ ) compared with $2.2 \%$ in lean patients (BMI < $30 \mathrm{~kg} \mathrm{~m}^{-2}$ ) [6]. Our patient had difficulty in mask ventilation, which was in accordance with previous studies. Two anesthetists provided the ventilation to the patient with the mask. All the preparations were ready in the operation room because of thought to be difficult ventilation and intubation. In contrast to the studies, endotracheal intubation was performed easily via direct laryngoscopy, without any intubation difficulties. It is important to ensure the safety of the patients with high body mass index during a surgical procedure. Due to the lack of a suitable hydraulic operating table for obese patients, two operating tables were joined to each other in order to sufficient space for the patient to fit on the tables in the suitable position for the surgical procedure. Thanks to this arrangement, the operation was carried out without any problems and there was no difficulty for the patient to have the suitable position for the surgery.

Physiological changes in obesity affect the distribution, binding and elimination of many drugs. Serious side effects may occur if the drugs are given according to the total weight of the obese patients [7]. The volume of distribution and clerens must be taken into account while dosing the drugs. Obese people can metabolize easly lipophilic drugs compared to other types of drugs. Weak or moderately lipophilic drugs are distributed mainly in lean tissues, and dosages must be calculated according to the ideal body weight. If the clearance is low or as low as a non-obese patient's, ideal body weight for the maintenance dose is taken as reference. If it is increased with obesity, then it can be based on total body weight for maintenance [8]. Regarding our patient's body mass index $(65.5 \mathrm{~kg} / \mathrm{m} 2)$, ideal body weight $(58.7 \mathrm{~kg})$ and lean body weight $(76.5 \mathrm{~kg})$, $0.5 \mathrm{mg}$ atropine, $2,5 \mathrm{mg} / \mathrm{kg}$ (due to LBW) propofol, $1 \mathrm{mcg} / \mathrm{kg}$ (due to LBW) remifentanil and $0.8 \mathrm{mg} / \mathrm{kg}$ (due to IBW) rocuronium bromide were administered after intravenous (IV) cannulation. During the operation $(6.5 \mathrm{hrs}) 80 \mathrm{mg}$ rocuronium was required. The choice of rocuronium bromide for patients, who are expected to have difficult intubations, is advisable because of the availability of specific antagonists [9]. Decurarization was performed with $2 \mathrm{mg} / \mathrm{kg}$ (due to IBW) sugammadex.
Atelectasia is more common in obese patients under general anesthesia than in non-obese patients and the recovery period is longer in the postoperative period [10]. Obese patients with sleep-apnea syndrome are more sensitive to respiratory depressant effects of hypnotics and opioids. Considering the aforementioned points, the follow-up was done in the recovery room of our patient, whose vitals were stable. Due to the complications arising from the respiratory distress, our patient was transferred to the intesive care unit where he stayed connected to the mechanical ventilator support for 2 days. Then the follow-up was performed by using the BIPAP device. The patient was transferred to the otolaryngology clinic on the 5th day of the follow-up and he was discharged completely after 14 days.

Obesity, which we started to see more frequently in patients undergoing surgery, is an important problem of the modern age. and being prepared for the problems that may develop on obese patient in the peroperative period makes safier approach for the patient and the physician. Being prepared in advance for the problems that may develop in the case of an obese patient in the peroperative period makes surgical procedures safier for both the patient and the physician. More cases should be discussed in the literature in order to determine the optimal anesthesia management in such patients.

\section{References}

1. Jones RL, Nzekwu MM. (2006) The effects of body mass index on lung volumes. Chest. 130:827.

2. Littleton SW. (2012) Impact of obesity on respiratory function. Respirology. 17:43.

3. Kabon B, Nagele A, Reddy D, et al. (2004) Obesity decreases perioperative tissue oxygenation. Anesthesiology. 100:274.

4. Langeron O, Masso E, Huraux C, et al. (2000) Prediction of dif $\neg$ ficult mask ventilation. Anesthesiology. 92:1229-1236.

5. Ezri T, Gewürtz G, Sessler DI, et al. (2003) Prediction of dif $\neg$ ficult laryngoscopy in obese patients by ultrasound quantification of anterior neck soft tissue. Anaesthesia. 58:1111 1114.

6. Juvin, Philippe MD, PhD; Lavaut, Elisabeth MD; Dupont, Hervé MD; Lefevre, Pascale MD; Demetriou, Monique MD; Dumoulin, Jean-Louis MD; Desmonts, Jean-Marie MD. (2003) Difficult Tracheal Intubation Is More Common in Obese Than in Lean Patients, Anesthesia \& Analgesia: August. 97(2);595-600.

7. Adams JP and Murphy PG. (2000) Obesity in anaesthesia and intensive care. Br J Anaesth. 85(1):91-108.

8. Lemmens HJ, Brodsky JB. (2006) The dose of succinylcholine in morbid obesity. Anesth Analg. 102:438-442.

9. Gencol, Tuba MD; Sergin, Demet MD; Balcioglu, Taner MD. (2019) Anesthetic Management of a Pediatric Patient With Bardet-Biedl Syndrome: A Case Report, A \& A Practice. 12(5);165-167.

10. Eichenberger A, Proietti S, Wicky S, et al. (2002) Morbid obe $\neg$ sity and postoperative pulmo $\neg$ nary atelectasis: An un $\neg$ derestimated sorun. Anesth Analg. 95:1788-1792. 